\title{
GROUNDWATER VARIABILITY IN BANGLADESH: ASSESSMENT BASED ON RAINFALL VARIATION AND USE OF WATER IN IRRIGATION
}

\author{
NAZMOON NAHAR SUMIYA ${ }^{1,}$ AND HAFIZA KHATUN \\ Department of Geography and Environment, University of Dhaka, Bangladesh
}

\begin{abstract}
This study attempts to portray the scenario of groundwater level with respect to rainfall variability and its use for irrigation purpose for rice production in Bangladesh. Data on groundwater level and irrigation water usage were collected from BWDB and BBS. The changing pattern of groundwater level are presented in maps using Inverse Distance Weighted (IDW) interpolation method in ArcGIS 10.3. Analysis shows the increasing dependency on groundwater than on surface water for irrigation purpose at varied range across the country. The groundwater level is declining at a higher rate in northern parts of the country than the southern parts. In the context of climatic variability, excessive use of groundwater can trigger the lowering of groundwater level which will require more energy to uptake water for irrigation and so the input cost of production of rice will be increased. Therefore, apposite measures are required to ensure sustainable use of groundwater resources.
\end{abstract}

Key words: Groundwater, Rainfall, Irrigation, Rice, Bangladesh

\section{Introduction}

Groundwater is an essential natural resource of our mother earth that constitutes about 95 per cent of the freshwater on our planet, making it fundamental to human life and economic development. The contribution from groundwater is vital; perhaps as many as two billion people depend directly upon aquifers for drinking water, and 40 per cent of the world's food is produced by irrigated agriculture that relies largely on groundwater (Morris et al. 2003). Bangladesh, a small country is blessed with plenty of water resources being located in the basins of mighty Ganges, Meghna, Barhmaputra and Karnaphuli rivers. With numerous rivers, Bangladesh is also affluent in groundwater resource. Since last couple of decades, groundwater is being extensively used for drinking, irrigation and several other purposes eventually declining the ground water level. Groundwater is a vital input for sustaining crop production.

Irrigation is the most important water use sector accounting for about 70 percent of the global fresh water withdrawals and 90 percent of consumptive water uses (Siebert et al. 2010). Availability of groundwater for irrigation has contributed to manifold increase in

${ }^{1}$ Research Assistant, Urban Studio, Department of Geography and Environment, University of Dhaka. 
crop productivity in Bangladesh (Dey et al. 2013). About 90 percent of irrigation water in Bangladesh is provided from groundwater (Zahid and Ahmed 2006). As a result of dense population and higher level of rural poverty, Bangladesh is very much in need of higher crop production. As far as the crop production is concerned, groundwater irrigation has contributed significantly to the rice production, mainly Boro rice, by supplementing soil moisture in the dry months of November/December to April/May (Kirby et al. 2014). The introduction of high yielding varieties (HYV) in 1980s revolutionized rice cultivation in Bangladesh. Increased water availability has encouraged farmers to grow irrigated Boro rice during the dry winter season. Thus, cropping pattern is being moved towards HYV rice. In the dry winter months, more than 70 percent of crop production is Boro rice, which can use up to $11,500 \mathrm{~m}^{3}$ per ha of water in the production process (Biswas and Mandal 1993 and Chowdhury et.al. 2013). Currently, about 4.2 million ha of land is irrigated by groundwater (both shallow and deep tube wells) whereas only 1.03 million ha is irrigated by surface water using low lift pumps (BADC 2013). Methods that are available to achieve these ends depend mainly on irrigation particularly minor irrigation technologies comprising low lift pumps (LLPs), deep tube wells (DTWs), shallow tube wells (STWs) and manually operated pumps (MOPs), which together are responsible for 85 percent of irrigation coverage in the country (Mondal and Wasim 2004). Qureshi et al. (2014) mentioned in a study that the principal supply of groundwater for irrigation is from shallow tube wells, the numbers of which have grown from around 100,000 in the early 1980 s to more than 1.5 million in 2010. At present, 35,322 DTWs are working in Bangladesh to provide water for irrigation purposes. Thus groundwater irrigation is of vital importance as an input to the agricultural economy and for food security (Haque et al. 2013). With increasing use of groundwater, the issues of sustainable groundwater usage are very much correlated. In several studies, it has been mentioned that falling groundwater levels in some areas have led to concerns about unsustainable groundwater use. Shamsudduha et al. (2009), Shahid and Hazarika (2010) and Kirby et al. (2016) in separate studies have agreed in the fact that groundwater use is unsustainable in some areas, such as the Barind area of northwest Bangladesh and around Dhaka. The reason behind such instability is reduced flow of river water in these regions and greater dependency on groundwater for irrigation purpose which has led to the excessive withdrawal of groundwater. Ali et al. (2012) mentioned that falling water levels in the northeast of Bangladesh are also due to excessive use of groundwater. Dey et al. (2013) also found a declining trend of groundwater table over the last 30 years (1981-2011) in their study, which implies groundwater use is not sustainable in northwest region. They identified the severely depleted district as Rajshahi followed by Pabna, Bogra, Dinajpur and Rangpur. They also mentioned about the increase of irrigation cost if the rate of dependence on groundwater for irrigation purpose increases. Therefore, it is clear that groundwater has been used extensively since before and this increasing rate of groundwater use may threaten the existing groundwater resource. Along with irrigation use, rainfall has also impact on groundwater recharge and so 
reduction in rainfall may affect lowering of groundwater level. Excessive lowering of groundwater level may results in scarcity of water, deteriorated water quality, increase of pumping cost and land subsidence. In the context of Bangladesh, rice production is largely dependent on groundwater irrigation alongside its overuse for drinking purpose. Therefore, it is important for everyone to know the consequences of unsustainable groundwater extraction and thus use groundwater optimally to maintain groundwater sustainability.

Several studies had been conducted regarding the water balance across the country, but each study claimed their limitations for being unable to assess the regional water balance precisely. Besides, study on the changing pattern of groundwater level has focused only on the northwester part of the country rather the rest of the regions. Despite being a small country, there lies spatial variability in the context of climate as well as in terms of groundwater fluctuation. So, at this state it is of utmost importance to explore the spatial variability of changing groundwater level to adopt effective measures to ensure sustainable use of groundwater. Therefore, this study is an effort to explore the changing pattern of groundwater level at spatio-temporal scale with response to rainfall variability and its use for irrigation purpose.

The aim of this study is to explore the spatial variability of groundwater level from 1985 to 2010 in the context of its use in irrigation purpose along with rainfall variation and to explore the impacts of variability on rice production in Bangladesh.

\section{Materials and Methods}

The spatio-temporal change of groundwater level was assessed based on the two-major rice growing seasons in Bangladesh. Aus, Aman are the traditional varieties of rice which grow in the months of wet season (March-April to October-November) whereas Boro rice grows in dry season (December to March-April). As both the growing period coincides the distinct seasons (wet and dry) thus analysis was made focusing on this seasonal variation along with spatio-temporal variation. Both quantitative and qualitative data were used to sketch the scenario of groundwater level fluctuation in response to its use for irrigation purpose and variability in seasonal rainfall. Rigorous reviewing of literature was conducted to get a strong background for this study. To explore the variability of groundwater level, data on groundwater level of 1097 wells distributed within the study area were collected from Bangladesh Water Development Board (BWDB) from 19852010. To investigate the contribution of groundwater resources for rice production through irrigation, historical data of irrigation usage for rice was collected from Yearbook of Agricultural Statistics of 1985-2011 published by Bangladesh Bureau of Statistics (BBS). Rainfall variability has been analyzed using the historical data (19812010) of rainfall from Bangladesh Meteorological Department (BMD). 
Collected data on groundwater level was sorted and categorized using MS Excel 2016. To portray the change of groundwater level at two different rice growing seasons, change of groundwater level was assessed separately both for Aus -Aman (wet) and Boro (dry) growing season for the year of 1985 and 2010. As groundwater level data are available from 1985 to 2010 comparison was made within this time period. The change in groundwater level was measured in terms of the groundwater level of 1985 from the water levels of 1990, 2000 and 2010. Thus, the negative values in change indicates an increase of groundwater level than the previous year level and the positive values reveal the decrease of water level which is presented in the maps. The maps, showing the changing pattern of groundwater level were prepared using Inverse Distance Weighted (IDW) interpolation method in ArcGIS 10.3. Besides, the usage of ground water for three major types of rice (Aus, Aman and Boro) was analyzed using MS Excel 2016. Change of average rainfall pattern of dry and wet season was assessed by calculating the collected rainfall data using MS Excel 2016. The changing scenario was presented in maps using Kriging Interpolation method in ArcGIS 10.3. Based on these analyzed data, groundwater variability was assessed.

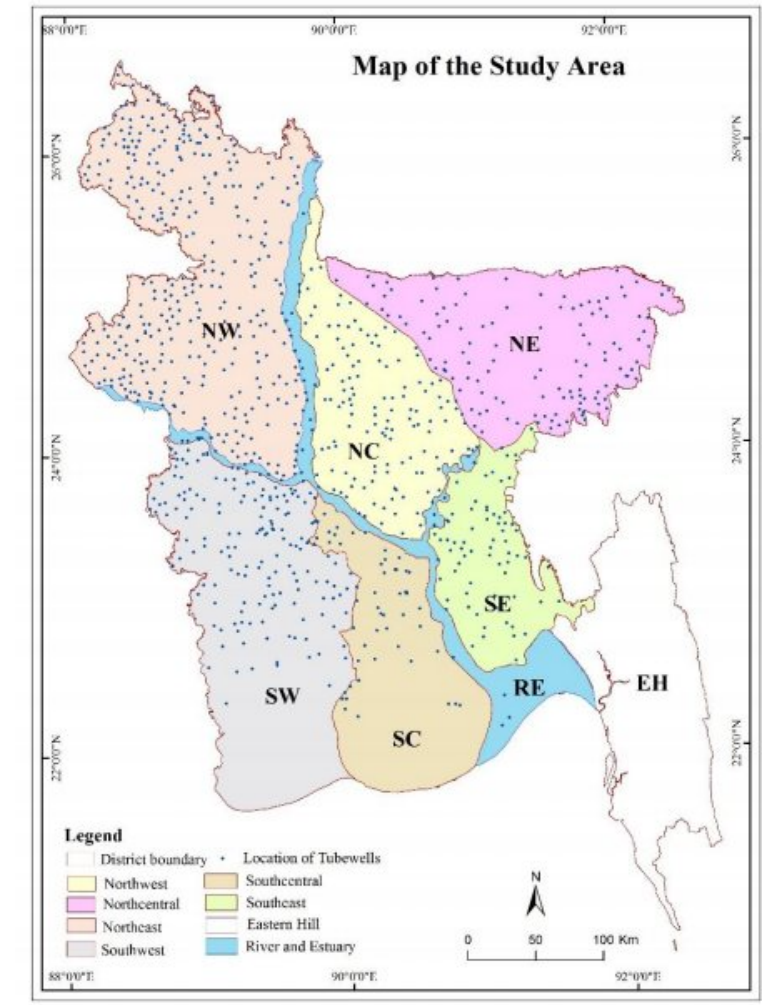

= Fig. 1. Map of the study area showing hydrological regions. (Source: Compiled from WARPO, 2004) 
Study Regions: This study is an attempt to reveal the spatial variation of groundwater level across the country and to correlate this variation along with its use for irrigation purpose. As the prime focus is to portray the variation at spatio-temporal scale, entire country is needed to categorize in several homogenous regions. Thus, the categorization of the study area was done on the basis of the hydrological regions of Bangladesh. In National Water Management Plan of 2004, Bangladesh had been classified in eight hydrological regions, based on appropriate natural features, for planning the development of their water resources (WARPO, 2004). These are Northwest (NW), Northcentral (NC), Northeast (NE), Southwest (SW), Southcentral (SC), Southeast (SE), Eastern hill (EH) regions and the active floodplains and charlands of rivers and estuaries (RE) which are presented in Fig. 1.

It is to mention that, the hydro-geological settings of the eastern hilly region are far different from the rest of the regions and it is also complex to explore the variability of groundwater level in this region. Besides, the rivers and estuaries have also excluded from this study. That is why, this study incorporates the Northwest, Northcentral, Northeast, Southwest, Southcentral, Southeast regions excluding the Eastern Hill region and rivers and estuaries.

Spatial Variability of Groundwater level: The spatio-temporal changes of groundwater level were analyzed by comparing the ground water level of 1985 and 2010. The comparison of average groundwater depth of 1985 and 2010 for both Aus-Aman (wet) and Boro (dry) growing season clearly indicates a variation in groundwater level which is not uniform across the study area. Fig. 2 represents the average groundwater level of 1985 in Aus-Aman and Boro growing seasons. It reveals that there lies marked seasonal variation in terms of water level across the country. The average groundwater depth is higher in northern regions than the southern regions.

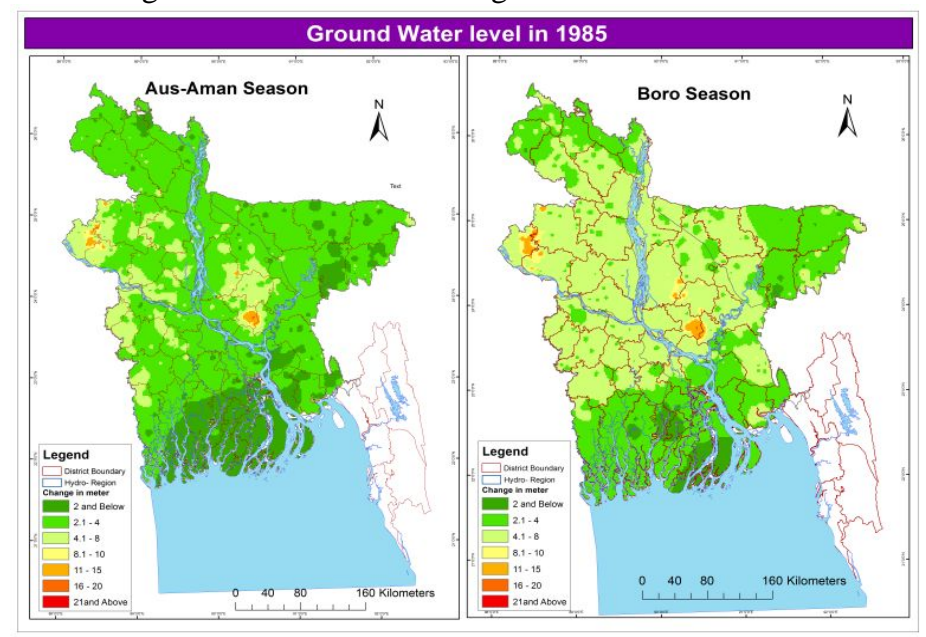

Fig. 2. Comparative scenario of groundwater level in Aus-Aman and Boro seasons in 1985. (Source: Prepared from collected data of 1985 from BWDB using IDW method) 
The average depth of groundwater level in wet season has found about $3.4 \mathrm{~m}$ and in dry season about $4.67 \mathrm{~m}$. About 1.8 percent of the total area had a water depth of more than $10 \mathrm{~m}$ in wet season whereas it was about 2.7 percent in dry season in 1985 (Fig. 2). It is also noticeable that the areas where water level is at a depth of more than $10 \mathrm{~m}$, are located in the northern regions. Similarly, the average groundwater level of 2010 (Fig. 3) shows continuous lowering of groundwater level in most cases.

Analysis showed that the average groundwater depth of wet season was $5.33 \mathrm{~m}$ while in dry season it was about $6.5 \mathrm{~m} \mathrm{2010.} \mathrm{To} \mathrm{quantify} \mathrm{the} \mathrm{change,} \mathrm{the} \mathrm{average} \mathrm{depth} \mathrm{of} \mathrm{ground}$ water level has declined about 7.8 percent in wet season and about 7.2 percent in dry season in 2010 than that of 1985. In Fig.4 the eventual change of groundwater level from 1985 to 2010 for both the seasons is presented. Analyzed data suggest varied declining trend of groundwater level except in some parts of the southern region. The average decline in groundwater level from 1985 to 2010 was found to be about $1.65 \mathrm{~m}$ in wet (Aus-Aman) season and $1.59 \mathrm{~m}$ in dry (Boro) season. For both the seasons, maximum decrease of groundwater level was found in northern regions. About 10 percent areas of the northern region have experienced a decline of more than $5 \mathrm{~m}$ within the last 25 years for both the seasons. In northern regions (NW, NC and NE), more than about 30 percent of the total study area have shown a decline of groundwater level more than $2 \mathrm{~m}$. In case of the rise of groundwater level, about 7-8 percent area have shown a rise of not more than $2 \mathrm{~m}$ in 2010 than in 1985 in wet season.

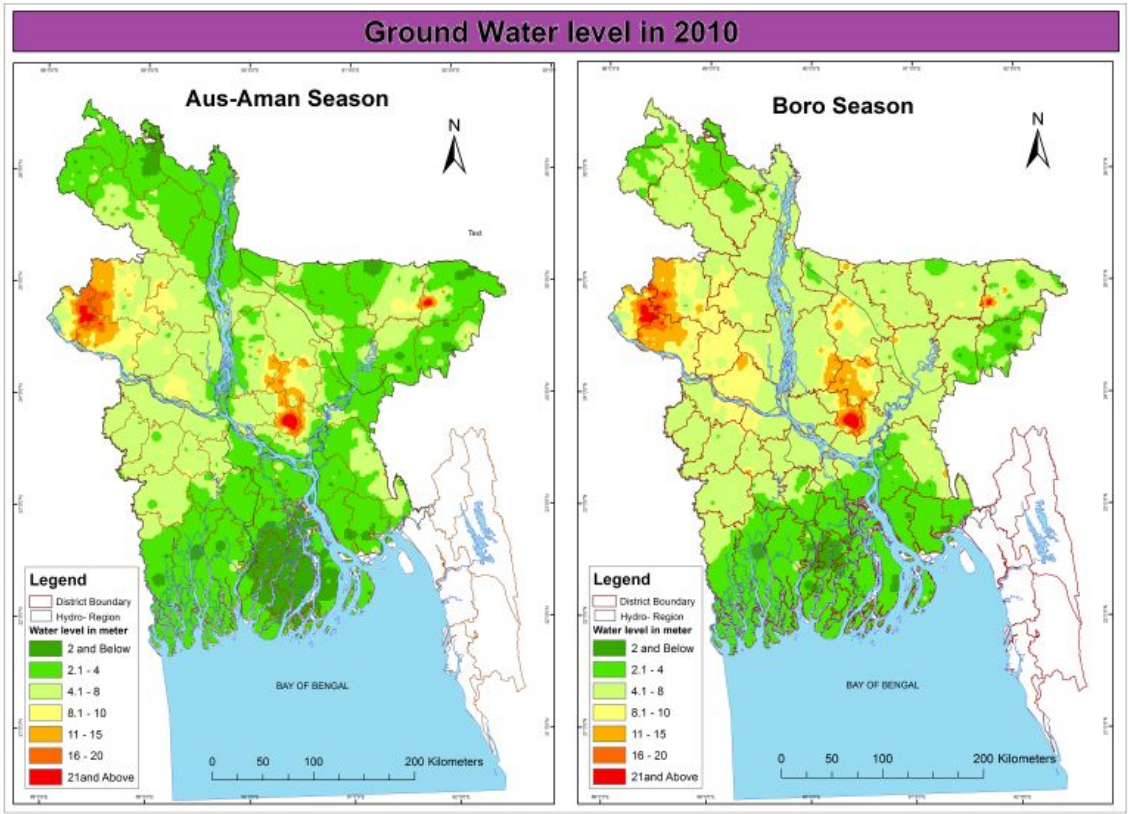

Fig. 3. Comparative scenario of groundwater level in Aus-Aman and Boro seasons in 2010. (Source: Prepared from collected data of 2010 from BWDB using IDW method) 
On the contrary, in about 12-15 percent area, water level rose not more than $2 \mathrm{~m}$. The rest of the parts of the study area showed a decline in groundwater level ranging from 0.01 to $2 \mathrm{~m}$.

Comparative scenario of groundwater level of 1985 and 2010 indicates overall decline in groundwater level. In 2010, the areas having groundwater depth more than $10 \mathrm{~m}$ from the surface has expanded to about 7.2 percent and 10 percent in wet and dry season from 1.8 percent and 2.7 percent in 1985 accordingly. In areas of northwest and northcentral region, water depth has declined more than $15 \mathrm{~m}$ that comprises almost 10 percent of the total study area. Another 10 percent area, surrounding the above zones are found at risk of depletion of water level to an extent of more than $10 \mathrm{~m}$.

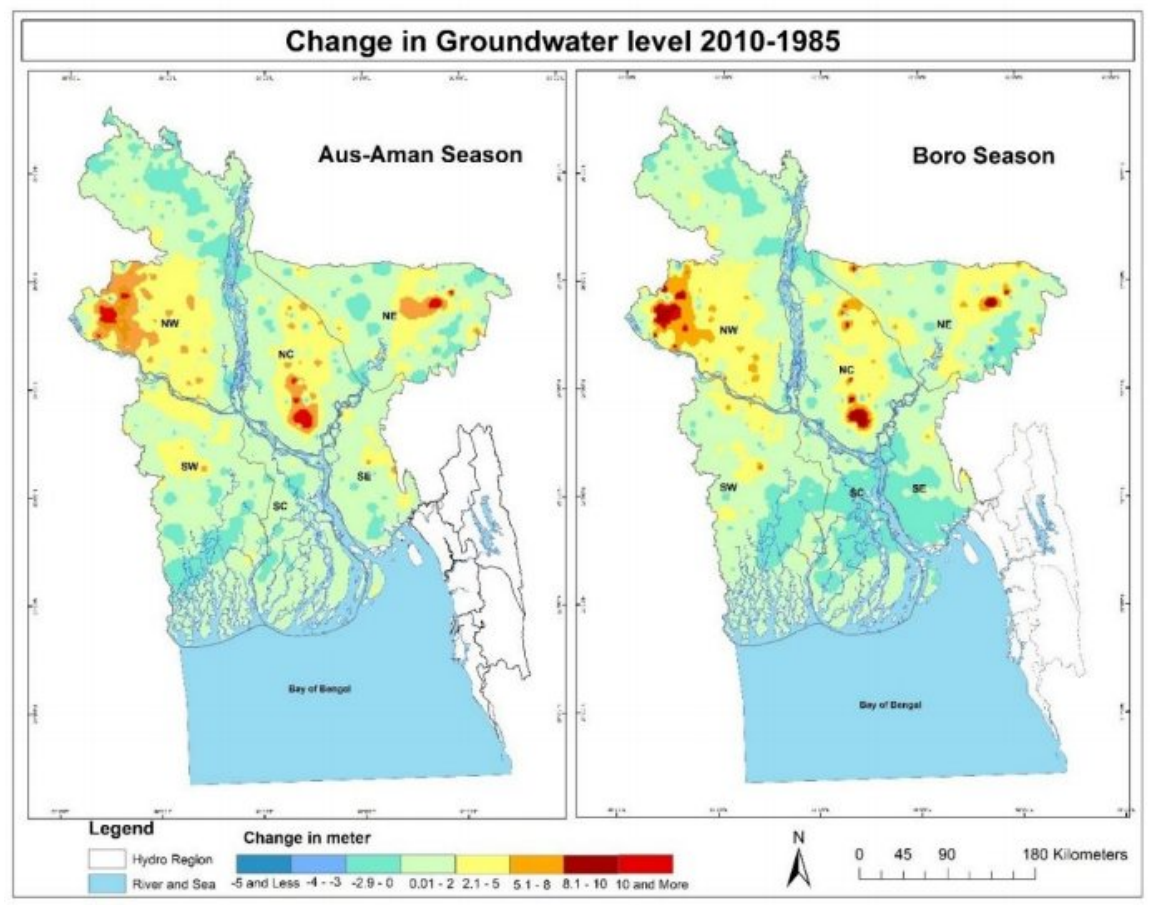

Fig. 4. Comparative changes in groundwater level from 1985 to 2010.

(Source: Prepared from collected data of 1985 to 2010 from BWDB using IDW method)

Rainfall Variability and Groundwater: In natural system, groundwater recharge largely depends on rainfall as it contributes to recharge directly the underlying aquifers. Jahan $e t$ al. (2010) has mentioned rainfall as the major source of groundwater recharge in Bangladesh and found that with the cessation of rainfall the major source for recharging groundwater also gradually stops. Adham et al. (2010) found that declining trend of rainfall with increased Potential Evapotranspiration, Crop Evapotranspiration and Net 
Irrigation, consequently depending more on groundwater results in a depleted trend in the groundwater table levels. In this study, along with the variability of groundwater level, variability of average annual rainfall was assessed which is presented in Fig. 5. The classification of wet and dry season rainfall was made based on the rice growing seasons as mentioned earlier. Variability in dry season rainfall affects the groundwater level of next wet (Aus-Aman) seasons and wet season rainfall affects its following dry (Boro) season water level.

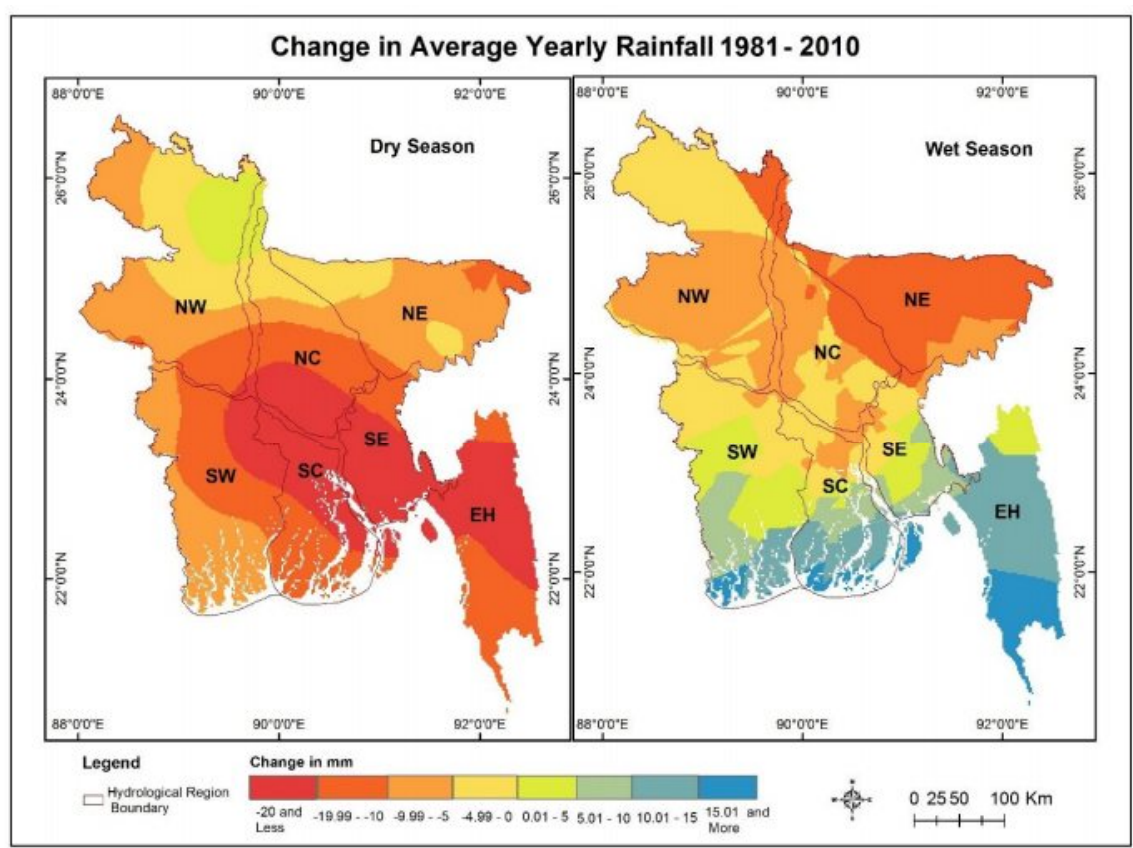

Fig. 5. Comparative changes in average rainfall from 1981 to 2010.

(Source: Prepared from collected data of 1981-2010 from BMD using Kriging method)

Comparative assessment of Fig. 4 and 5 reveals that the fluctuation of groundwater level is significantly related to the changing scenario of average seasonal rainfall. Evident decrease in rainfall of dry season particularly in southcentral, southeast, southwest, northcentral and northeast parts has consequently triggered the lowering of groundwater level in Aus-Aman growing season. A little increase in average rainfall in the northern part of northwest region may have resulted in the rise of water level in this part which is evident in Fig. 4.

Similarly, the increase of average rainfall in southern regions have resulted in the rise of average groundwater level in some parts of southwest, southcentral and southeast region in Boro season (Fig. 4). Despite known as the haor region, there has been a visible decline in groundwater level which may have accelerated by the decrease of rainfall in 
this region (Fig. 5). In several studies, it has come out that the rivers of the northwest region have dried up severely that has put an excessive pressure on groundwater resource in this region and so, in spite of minimum decrease in average rainfall, the water level is declining at an alarming rate in northwest and northcentral region.

Groundwater Variability and its Use in Irrigation: Rice is the largest irrigation water user, accounting for about 77 percent of the total irrigated area (BBS 2014) and Bari and Anwar (2000) found that about 75 percent water for irrigation comes from groundwater. Traditionally Bangladesh is known as riverine country and it has an enriched history of using river water for various purposes. Historical evidences indicate that, river or canal water was the prime source of irrigation water earlier. With the advent of time as well as introduction of high yield varieties especially after 1980s, the dependency on groundwater for irrigation increased significantly across the country. Rasheed (2016) claimed in his study that in mid -1970s, surface water was the potential source of irrigation accounting for 92 percent of the total irrigated area. Since 1986-87, phenomenal expansion of groundwater utilization for irrigation has noticed (Rasheed 2016). In several researches, Boro rice has been considered as the most irrigation intensive rice varieties. In this study, use of groundwater for irrigation of rice was considered as one of the factors that affect the decline of groundwater level. Analyzed data show that, among the three varieties of rice, Boro rice is the most irrigation intensive rice whereas Aus and Aman rice require less irrigation (Fig. 6). The irrigated area under Boro rice production is 31 times higher than Aus growing area and 10 times of Aman growing irrigated areas.

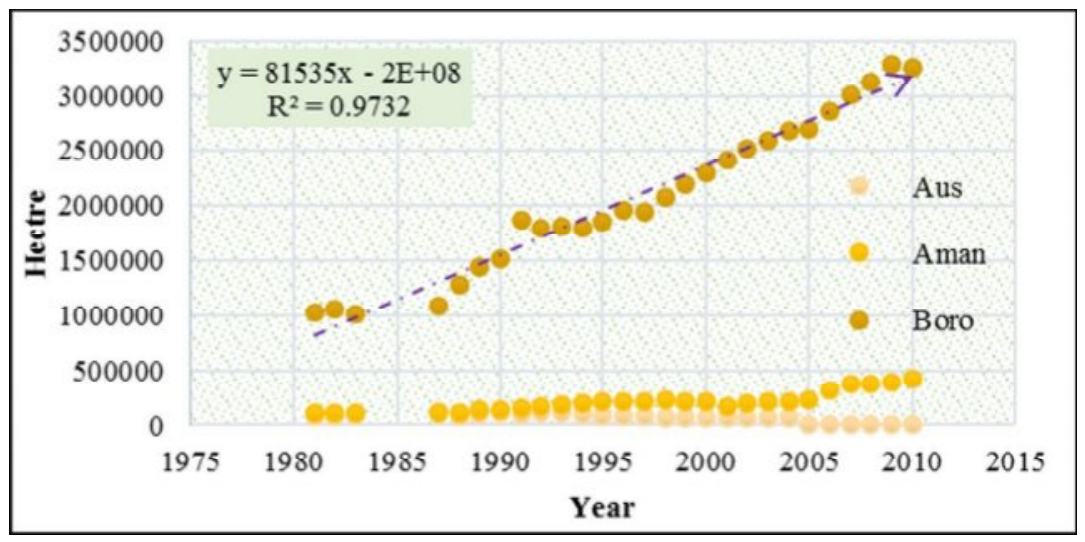

Fig. 6. Use of irrigation water for the production rice varieties in Bangladesh.

(Source: Analyzed from collected data of 1981-2010 from BBS)

Likewise, the spatial variation of groundwater and rainfall, the use of groundwater for irrigation are not uniform across the study area. The maximum use of groundwater for irrigation was observed in southwest region, followed by northwest and north central 
region, while the least use has seen in northeast region. The southwest region is like the west, affected by low water availability in the dry season and salinity problems has caused dependency on groundwater for irrigation development (Kirby et al. 2014). Accordingly, with the variability of rainfall in southern regions, increase of groundwater use for irrigation than surface water was evident (Fig. 7).

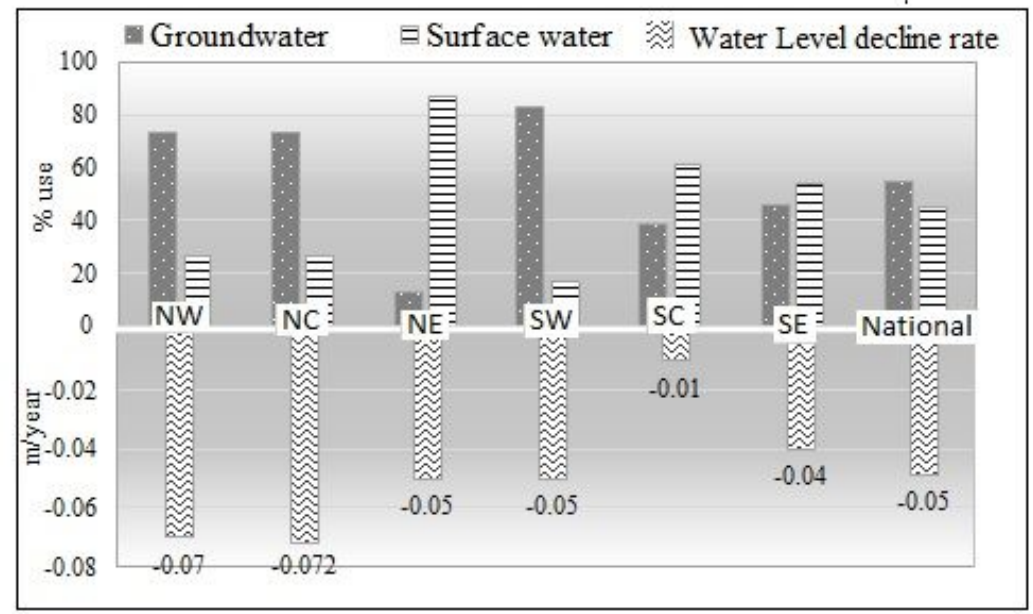

Fig. 7. Use of groundwater for irrigation and groundwater level decline rate 1985-2010.

(Source: Author's own calculation based on the data of 1985-2010 from BWDB and BBS)

It is known that ground water is largely used for drinking and other purposes together with its use for irrigation purpose. Keeping aside the use for drinking purpose, only irrigation usage and associated change has observed in this study. Based on the analysis, it was found that the declining rate of groundwater is highest in northcentral region $(0.072 \mathrm{~m} /$ year $)$ and minimum in southcentral region $(0.01 \mathrm{~m} /$ year $)$ whereas the average rate of groundwater decline was found to be $0.049 \mathrm{~m} / \mathrm{year}$ (Fig. 7). The average groundwater level decline rate from 1985 to 2010 was found to be $0.05 \mathrm{~m} /$ year across the study area whereas Zahid and Ahmed (2006) estimated the lowering trend of groundwater level during the last 32 years is 20 to $30 \mathrm{~m}$ with an average decline of more than $1.0 \mathrm{~m} /$ year. Undoubtedly, extraction of groundwater for irrigation has adversely affected the lowering process of groundwater level regionally.

Climate Variability, Irrigation and Groundwater Sustainability: Climatie variability (change) has been the global concern since last couple of decades. In the context of climate change, the average temperature and rainfall pattern of this country have not remained the same as before. Studies showed that, the average temperature is increasing countrywide along with variation in rainfall pattern (Sumiya 2016). Assumptions can be made that the variation of temperature and rainfall will affect the groundwater recharge while more dependency on groundwater for irrigation may occur to ensure food security. In the present study, it was found that with the decrease of rainfall, decline of 
groundwater level has occurred. Despite decrease of rainfall regionally, the production of rice has shown manifold increase across the country. Sumiya (2016) mentioned that the seasonal rainfall pattern is changing and the adverse impact of such changes in rainfall distribution on rice production has been minimized through extensive irrigation using ground water. As a result, in the context of future climate change, the overuse of groundwater may threaten the sustainability of groundwater resource of the country.

Apart from these, it was found that greater areas of northern regions have a water level at a depth of more than $10 \mathrm{~m}$. It is said that, if the groundwater level is at a depth of more than $10 \mathrm{~m}$ from the surface, additional force is required to withdraw water from the ground which ultimately increases pumping cost and the input cost of rice production. Indirectly, the rice production may face instability in response to its dependency on groundwater for irrigation.

In Bangladesh, along with drinking purpose, groundwater is widely used for irrigation. Among the three varieties of rice, irrigation is largely required for Boro production. Variability of rainfall has also increased the use of irrigation for Aus and Aman rice production too. The contribution of groundwater in irrigation has increased from 41 percent in 1982/1983 to 75 percent in 2001/2002 and surface water has declined accordingly. This study reveals that the contribution of groundwater in irrigation has increased from 38 percent in 1980/1981 to 78 percent in 2011/12 and surface water has declined from 62 percent to 22 percent accordingly. Thus, there has been a distinct decline in ground water level across the country with some exception. The declining rate of groundwater is higher in northern regions in comparison with the southern region. Though, rice production has increased dramatically in recent years than the past, it is time to ensure its progression by ensuring the availability of all the external inputs like groundwater. In this context, proper measures should be taken to ensure sustainable use of groundwater. New rice varieties which require less irrigation should be invented so that it can minimize the use of groundwater for irrigation purpose. Moreover, groundwater has proved one of the major inputs of rice production and so proper attention should be given on sustainable use of groundwater that compliments the development of rice production.

\section{References}

Adham, M.I., C.S. Jahan, Q.H. Mazumder, M.M.A. Hossain and A.M. Haque. 2010. Study on Groundwater Recharge Potentiality of Barind Tract, Rajshahi District, Bangladesh Using GIS and Remote Sensing Technique. Journal of Geological Society of India, 75.

Ali, M.H., A.A. Sarkar and M.A. Rahman 2012. Analysis on Groundwater-Table Declination and Quest for Sustainable Water Use in the North-Western Region (Barind Area) of Bangladesh. Journal of Agriculture Science and Applications, 1(1): 26-32.

BADC 2013. Survey Report on Irrigation Equipment and Irrigated Area in Boro-2012 Season. Bangladesh Agricultural Development Corporation, Dhaka. Available at: www.badc. gov.bd. 
Bari, M.F. and A.H.M.F. Anwar. 2000. Effects on Irrigated Agriculture on Groundwater Quality in Northwestern Bangladesh. In: Proceedings of Integrated Water Resources Management for Sustainable Development. New Delhi , I:19-21.

BBS. 2014. Agricultural Statistical Yearbook of Bangladesh. Bangladesh Bureau of Statistics, Statistics Division, Ministry of Planning, Government of the People's Republic of Bangladesh, 259-264.

Biswas, M.R. and M.A.S. 1993. Mandal Irrigation management for crop diversification in Bangladesh. University Press Ltd.

Choudhury, S.A., T. Terao, F. Murata and Hayashi, T. 2013. Seasonal Variations of Temperature and Rainfall Characteristics in the Northeastern Part of Bangladesh Around Sylhet. Journal of Agroforestry and Environment, 6.

Dey, N. C., S. K. Bala, Saiful, A. Islam and M. A. Rashid. 2013. Sustainability of Groundwater Use for Irrigation in Northwest Bangladesh. Policy Report prepared under the National Food Policy Capacity Strengthening Programme (NFPCSP). Dhaka, Bangladesh.

Haque, M. A., M. S. Islam and A. Zahid. 2013. Groundwater Irrigation and Crop Economy in the Lower Gangetic Plain at Matbarer Char, Madaripur, South-Central Bangladesh. Journal of the Asiatic Society of Bangladesh, Science, 38: 29-39.

Jahan, C.S., M. A. Islam, Q.H. Mazumder, M. Asaduzz aman, M. M. Islam, M.O. Islam and A. Sultana. 2007. Evaluation of Depositional Environment and Aquifer Condition in Barind Area, Bangladesh using Gamma Ray Well Log Data. Journal of Geological Society of India, 70:1070-1076.

Kirby, J., M. Mainuddin, F. Mpelasoka, M. Ahmad, W. Palash, M. Quadir, S. Shah-Newaz and M. Hossain. 2016. The Impact of Climate Change on Regional Water Balances in Bangladesh. Climatic Change, 1-11.

Kirby, M., M. D. Ahmed, M. Mainuddin, W. Palash, E. Qadir and S. M. Shah-Newaz 2014. Bangladesh Integrated Water Resources Assessment, Supplementary Report: Approximate Regional Water Balances. CSIRO, Australia, 1-50.

Mondal, M.S. and S. A. Wasimi. 2004. Impact of climate change on dry season water demand in the Ganges Delta of Bangladesh: In M.M. Rahman, M.J.B. Alam, M.A.Ali, M. Ali. and K. Vairavamoorthy edited Contemporary Environmental Challenges. Centre for Environmental and Resource Management (CERM) and International Training Network (ITN) Centre, Bngladesh University of Engineering and Technology and Lough Borough University, UK.

Morris, B. L., A. R. Lawrence, P. Chilton, B. Adams, R. C. Calow and B. A. Klinck 2003. Groundwater and Its Susceptibility to Degradation: A Global Assessment of the Problem and Options for Management, Report Series, United Nations Environment Programme.

Qureshi, A. S., Z. Ahmed and T. J.Krupnik. 2014. Groundwater Management in Bangladesh: An Analysis of Problems and Opportunities, Cereal Systems Initiative for South Asia Mechanization and Irrigation (CSISA-MI) Project, Research Report No. 2., Dhaka, Bangladesh, 15-20.

Rasheed, K.S. 2016. Bangladesh: Resource and Environmental Profile. AH Development Publishing House, Dhaka, Bangladesh.

Shahid, S. and M.K. Hazarika. 2010. Groundwater Drought in the Northwestern Districts of Bangladesh. Water Resources Management. 24(10): 1989-2006.

Shamsudduha, M., R.E. Chandler, R.G. Taylor and K.M. Ahmed. 2009. Recent Trends in Groundwater Levels in a Highly Seasonal Hydrological System: The GangesBrahmaputra-Meghna Delta. Hydrology and Earth System Sciences, 13: 2373-2385.

Siebert, S., J. Burke, J.-M. Faures, K. Frenken, J. Hoogeveen, P. Döll and F. T. Portmann. 2010. Groundwater Use for Irrigation-A Global Inventory. Hydrology and Earth System Sciences, 14: 1863-1880.

Sumiya, N. N. 2016. Climate Change and Rice Production in Bangladesh: An Assessment Based on the Spatio-Temporal Variability of Temperature, Rainfall and Groundwater Level. 
Masters of Science Unpublished thesis, Department of Geography and Environment, University of Dhaka, 117-156.

WARPO. 2004. National Water Management Plan. Ministry of Water Resources, Government of the People's Republic of Bangladesh. 2:14-16.

Zahid, A. and S. R. U. Ahmed. 2006. Groundwater Resources Development in Bangladesh: Contribution to Irrigation for Food Security and Constraints to Sustainability. Groundwater Governance in Asia, Series-1: 25-46.

(Revised copy received on 6/10/2016) 